Canadian University Music Review

Revue de musique des universités canadiennes

\title{
John Rosselli. The Opera Industry in Italy from Cimarosa to \\ Verdi: The Role of the Impresario. Cambridge: Cambridge \\ University Press, 1984. viii, 214 pp.
}

\section{Kenneth DeLong}

\section{Numéro 6, 1985}

URI : https://id.erudit.org/iderudit/1014077ar

DOI : https://doi.org/10.7202/1014077ar

Aller au sommaire du numéro

Éditeur(s)

Canadian University Music Society / Société de musique des universités canadiennes

\section{ISSN}

0710-0353 (imprimé)

2291-2436 (numérique)

Découvrir la revue

Citer ce compte rendu

DeLong, K. (1985). Compte rendu de [John Rosselli. The Opera Industry in Italy from Cimarosa to Verdi: The Role of the Impresario. Cambridge: Cambridge University Press, 1984. viii, 214 pp.] Canadian University Music Review / Revue de musique des universités canadiennes, (6), 342-345.

https://doi.org/10.7202/1014077ar

(c) Canadian University Music Society / Société de musique des universités canadiennes, 1985
Ce document est protégé par la loi sur le droit d'auteur. L’utilisation des services d'Érudit (y compris la reproduction) est assujettie à sa politique d'utilisation que vous pouvez consulter en ligne.

https://apropos.erudit.org/fr/usagers/politique-dutilisation/ 
brilliant or avant-garde work, but a solid account of, for that time, traditional chant theory.

Do we really need a new edition? The Lucidarium has flickered most brightly in this century through the edition of Martin Gerbert (Scriptores, III, $64 \mathrm{ff}$ ) - the only available "modern" edition - though the Pomerium has fared better. It is now the sacredly de rigueur credo of medievalists to discredit Gerbert. So it is not surprising to read in Herlinger's preface that Gerbert's edition "abounds in errors and omissions" and that it "misrepresents" Marchetto's ideas. How inaccurate is the older edition? There are spellings, word inflections, punctuation, occasional words, and numbering which differ from those of the new edition, but these are usually trivial and do not distort the content. Gerbert employed two sources, Herlinger eighteen. The effort required to tackle the other sixteen must surely have led to diminishing returns. For most of the treatise, Gerbert is perfectly adequate. As for the musical examples, Gerbert's differ in ligation, barring, graphics, and occasionally in pitch, but not enough to obfuscate Marchetto's meaning. Seldom could these variants reasonably be considered misrepresentation. The new edition is undoubtedly better, of course, but the old is far from useless, especially to the scholar with an experienced eye to the common calligraphic and grammatical carelessness characteristic of medieval manuscripts, factors which seem to be amply illustrated in the eighteen variants of Lucidarium.

There is little originality, nor much scope for it, evident on the part of the editor of the new Lucidarium. Since the bulk of the work is Marchetto's, however, the editing and translation are for the most part thorough and sound. In the Introduction, where we do hear directly from the editor, there is the briefest biographical sketch of Marchetto (little is known of the man), an attempt to date the treatise, some shuffling of secondary sources, and an attempt (albeit muted) to aggrandize the historical position of Lucidarium. Following is a list of source manuscripts with sigla, an extensive inventory of their contents, references to other inventories, and stemmatic schemes which at tempt to establish relationships among the manuscripts - all the favorite games of current medievalism. The editor adds little that was not already known in the Introduction nor is the translation necessary for the serious scholar. But it is not likely, mainly because of the edition, that anyone will have to replicate this task for some time to come. The light will sputter on, even if in a void.

Bryan Gillingham

JoHn RosseluI. The Opera Industry in Italy from Cimarosa to Verdi: The Role of the Imnpresario. Cambridge: Cambridge University Press, 1984. viii, $214 \mathrm{pp}$. 
an account of opera during Italy's "Golden Century" (William Weaver) from a perspective little considered by most operatically inclined academics or opera buffs. Instead of the usual discussion of composers, works, and singers, Rosselli views his subject from the bottom up, from the standpoint of those ultimately responsible for making individual performances, and even whole seasons, of opera actually happen - the impresarios. In doing so, Rosselli has produced that academic rarity, a genuinely unique book, one that is not only immensely entertaining and informative, but also one that provides some useful reflections upon the various factors, artistic and financial, that governed the development of Italian opera from the ancien régime to the founding of modern Italy in the 1870 s.

As Rosselli himself points out in his "Note on further reading," "This book is the first attempt to deal systematically with Italian opera as a business, and with impresari and agents as a group" (p. 205). Being new, it follows that the book is based upon sources hitherto little examined by other writers. Not content with consulting volumes on social, economic, and musical history, Rosselli has investigated the diaries and papers of innumerable impresarios, agents, and sundry surrounding operatic hangers-on, and has also dug deep into the theatrical and business archives of virtually every town and city of operatic consequence in Italy. The fruit of this remarkable industry is a significant and important work of musical sociology.

Who were these impresarios? What sort of people were they and where did they come from? What did they actually do? What was their relationship to the composers? When and why did they eventually die out? In an account that is at once terse and packed with information, Rosselli answers all these questions and more. Roselli has a keen eye for the anecdotal, and in his rummaging through city archives, professional papers, and letters, he has come up with some striking, even startling facts. For example, if after months of careful preparation, fortuitous casting, and more than a little luck, an opera was deemed successful, the impresario might bask in widespread public acclaim and even be the focal point for a torchlight procession. He could, and often did, make large sums of money. If, on the other hand, his opera flopped, his very safety might be in jeopardy, as was the case after an unfortunate performance of L'Elisir d'amore in Rome in 1834, when the audience could be heard chanting "send the impresario to jail" (p. 156). After one particularly disastrous flop in Parma in 1818, the impresario Osea Francia was arrested on the spot and put in the fortress. Another had a bench thrown at him from the fifth tier; and one even took poison after suffering a season of overwhelming losses at Venice's Teatro La Fenice in 1794. Most impresarios, however, appear to have been energetic, if sometimes unscrupulous, entrepreneurs who had an irrational love of the theater and who also loved a challenge.

Although they wielded enormous power, often extending into every 
facet of opera production, most impresarios are today obscure figures and are rarely known by name. Well established by Mozart's time, enough so to inspire his comic opera, the impresarios seem to have had their heyday during the first half of the nineteenth century, when in conjunction with and supported by the nobility they exercised a virtual monopoly over Italian operatic life. However, aside from Bartolomeo Mireli (1794-1879), known because of his close association with Verdi, and Domenico Barbaja (1778-1841), who ran theaters in Naples and Vienna for over thirty years, the figure of the impresario crops up only fleetingly in most accounts of Italian opera. Even Mirelli, despite his Verdi connection, rates only a few passing pages in Julian Budden's magisterial three-volume study, The Operas of Verdi, and little more in David Kimbal's seven hundred-page Verdi in the Age of Italian Romanticism.

Rosselli begins his account with a chapter entitled "A Season in the Life of an Impresario" in which he chronicles the events of a typical operatic season during the Restoration and describes the hurdles an impresario often had to surmount in the course of a season. A superb bit of descriptive historical writing, it provides a neat synoptic view of the entire subject. This is followed by chapters which profile some of the more influential impresarios (including the Marchese Cavalli, Alessandro Lanari, and the Marzi brothers) and describe their relationships with their employers (the nobility and civic consortiums that controlled the theaters), and also their relationships with the singers and production staff. The central and longest portion of the book is devoted to an account of the impact of repressive authority upon the impresarios, the effect of the upheavals of 1848 upon operatic life, and some details of how operatic business was actually conducted. Roselli even provides tables listing the fiscal expenditures for individual seasons of opera in selected towns and cities from the beginning of the eighteenth century to 1865. The book closes with an amusing, anecdotal chapter dealing with the impresario and his public, and a final speculative chapter discussing the end of the impresarios.

In his summary Roselli likens the impresarios to the Hollywood magnates of the 1930s who owned a stable of actors, script-writers, and scenic designers, and whose word was law. In similar fashion, the impresarios often had their own stable of singers, set designers, costume makers, and even orchestral players - all of whose services were jealously guarded and sold for the best prices possible. Thus, in an age of authority and repression, the impresario emerges as one of the first free enterprise figures, one who lived by his wits, by his organizing ability, and by sheer effrontery. If some were rogues who absconded with the profits and left the singers penniless, others were dedicated men of the lyric theater who often possessed prodigious energy. Since the business was riddled with legal contracts, lawsuits, and correspondence of every sort, the impresario had to be all things to everyone. At his career peak, for example, Mirelli appears to have written about 8000 letters per year, an 
average of twenty-two each day, dealing with every conceivable aspect of the opera business.

Rosselli sees the decline of the impresario as stemming from two principal causes: (1) the gradual democratization of audiences in the years approaching 1870, and (2) the gradual passing of authority to publishers and, to a lesser degree, composers. By the end of the century, for example, opera in Milan was dominated not by an impresario but by Guilio Ricordi (publisher of both Verdi and Puccini), who controlled not only casting but all other phases of opera production. Clearly a new day had dawned, one in which the by now old-fashioned impresario was obsolete. Moreover, opera was by this time largely a repertory affair, with seasons increasingly devoted to the performance of a small number of established works, a situation that still obtains today. The number of new operas produced at Naples' Teatro San Carlo reached a high of thirty-eight in the 1831-40 decade, dropping to one or two per year during the 1860s. The impresarios did not survive the changes of these decades and by the end of the century were largely extinct. During their time, however, they had a powerful impact upon the way in which opera was produced and even composed, and their story clearly deserves to be told. Urbane, literate, witty, and scholarly without being in the least bit pedantic, Rosselli's book tells the story of the impresarios, and in doing so makes a valuable contribution to the history of the genre.

Kenneth DeLong

LINDA SIEgel. Music in German Romantic Literature: A Collection of Essays, Reviews and Stories. Novato, California: Elra Publications, 1983, xii, $287 \mathrm{pp}$.

With her book, Music in German Romantic Literature: A Collection of Essays, Reviews and Stories, Linda Siegel offers an interesting, wellwritten, carefully edited, but somewhat puzzling contribution to the subject of the interrelationship between music and literature during the period of German Romanticism.

The title of any book, but especially the title of an interdisciplinary study such as this one, should indicate quite clearly what the reader can expect to find. Given the book's title, this reviewer was somewhat surprised by the choice of texts. Although some of the well-known Romantics, Tieck, Arnim, Kleist, Eichendorff, and Körner, are represented, there are also almost thirty pages devoted to Ludwig Börne, a name which is not associated with German Romanticism either in the standard histories or in annual bibliographies of German literature. E.T.A. Hoffmann, author of one of the most well-known German Romantic texts dealing with music, is completely absent. Robert Schumann, another name not usually associated with German literature, 